\title{
Isolasi Gen Penyandi Peroksidase melalui Penapisan terhadap Pustaka Genom Kedelai Kultivar Slamet
}

\author{
Suharsono ${ }^{\left.1,2^{*}\right)}$, Faisal Rachman ${ }^{1)}$, dan Utut Widy Astuti ${ }^{1,2)}$ \\ 1)Pusat Penelitian Sumberdaya Hayati dan Bioteknologi IPB, \\ Jl. Kamper Gd PAU, Kampus IPB Darmaga, Bogor 16680 \\ 2)Departemen Biologi, FMIPA IPB, Gd. Fapet Wing 1 Lt 5, Kampus IPB Darmaga, Bogor 16680 \\ Diterima 09-01-2009 Disetujui 15-05-2009
}

\begin{abstract}
Screening to genomic library of soybean cultivar Slamet in ë phage to isolate the gene encoding for peroxidase (per) was performed by two steps. cDNA of per gene from Arabidopsis thaliana labeled by alkalin phosphatase was used as probe. The first screening was done by using $10^{5}$ recombinant pfu (plaque forming unit). The second screening was carried out on $\mathbf{1 0 0}$ recombinant pfu isolated from the first screening. The result of second screening showed that all screened clones were supposed containing per gene. The ë phage resulted from second screening was infected into $E$. coli BM 25.8. Due to the Cre recombinase in $E$. coli BM 25.8, two lox $P$ sites flanking the insert DNA of soybean created recombination. The recombination in loxP sites resulted the excision and formed recombinant plasmid containing per gene of soybean. To multiply, the recombinant plasmid was introduced into $E$. coli DH5á. Analysis southern hibridization of recombinant plasmid cut by Bam $\mathrm{HI}$ showed that Bam $\mathrm{HI} 3.7 \mathrm{~kb}$ fragmen of S52121R clone, 5,3 kb of S2412R clone, 2,4 and 5,3 kb fragments of S2532R clone were supposed to contain per genes.
\end{abstract}

Keywords: genomic library, peroxidase gene, screening, soybean

\section{PENDAHULUAN}

Produksi pertanian secara nasional dapat ditingkatkan melalui program intensifikasi dan ekstensifikasi. Kedua program tersebut sangat membutuhkan kultivar unggul. Perakitan kultivar unggul sangat ditentukan oleh ketersediaan gen sasaran. Oleh sebab itu isolasi gen mempunyai peranan yang sangat penting untuk peningkatan produksi pertanian.

Salah satu kendala dalam perluasan areal pertanaman kedelai adalah keterbatasan lahan subur. Di lain fihak, terdapat lahan marginal yang sangat luas yang belum dimanfaatkan secara optimal. Salah satu lahan marginal yang cukup luas di Indonesia adalah tanah asam podsolik merah kuning dengan luas 47.6 juta ha (Syarifuddin \& Abdurachman, 1993) yang mempunyai kelarutan aluminium (Al) tinggi.

Al adalah toksik bagi tanaman. Dalam keadaan asam, Al mempunyai kelarutan yang tinggi sehingga dapat diserap tanaman. Oleh sebab itu, pada tanah asam, Al menjadi berbahaya bagi tanaman.

Gen yang ekspresi diinduksi oleh cekaman Al mempunyai peranan dalam sistem toleransi tanaman

\footnotetext{
*Telp: +628128812239

Email:suharsono@yahoo.com
}

terhadap cekaman asam dan Al. Oisolasi gen yang ekspresinya diinduksi oleh cekaman asam dan Al menjadi sangat penting. Isolasi gen melalui penapisan terhadap pustaka genom memungkinkan untuk mengisolasi gen secara utuh, termasuk daerah intron dan pengendali ekspresinya seperti promoter dan terminator. Pustaka genom tanaman kedelai kultivar Slamet yang merupakan kultivar toleran terhadap cekaman aluminium telah berhasil dikontruksi oleh Suharsono (2002). Dengan menggunakan pelacak DNA atau gen yang ekspresinya diinduksi oleh $\mathrm{Al}$, baik yang berasal dari tanaman kedelai maupun dari tanaman lain yang mempunyai homologi dengan DNA kedelai, maka seluruh gen-gen yang ekspresinya diinduksi oleh $\mathrm{Al}$ pada tanaman kedelai dapat diisolasi dan dipelajari karakternya.

Peroksidase merupakan enzim oksidoreduktase yang menggunakan hidrogen peroksida sebagai substrat. Peroksidase berhubungan erat dengan proses fisiologis seperti penyembuhan luka, oksidasi fenol, dan sistem pertahanan tanaman terhadap serangan patogen. Ekspresi gen penyandi peroksidase diinduksi pada saat perkembangan dan perkecambahan embrio pada kapas (Ritter et al., 1993). Ekspresi gen penyandi 
peroksidase di tanaman transgenik Solanum integrifolium meningkatkan kandungan lignin yang mengakibatkan tanaman tersebut toleran terhadap ulat Spodoptera litura dan Heliothis armigera (Tsuduki et al.,2006).

Ekspresi gen peroksidase diinduksi oleh cekaman Al pada Arabidopsis thaliana (Richards et al., 1998; Zhao et al., 2009). Ekspresi copper-zinc superoksida dismutase (CuZnSOD) dan askorbat peroksidase (APX) secara berlebih menyebabkan kenaikan toleransi tumbuhan terhadap methyl viologen pada rumput Festuca arundinacea (Lee et al., 2007), dan kentang (Tang et al., 2006), ion logam Cu, Cd, dan As (Lee et al., 2007) dan temperatur yang tinggi (Tang et al., 2006). Tanaman tembakau transgenik yang mengekspresikan CuZnSOD, APX dan dehydroascorbate reductase (DHAR) secara simultan di kloroplast adalah sangat toleran terhadap cekaman $\mathrm{NaCl}$ dan paraquat (Lee et al., 2007). Aktivitas enzim peroksidase meningkat pada biakan sel tembakau yang mendapat cekaman kadmium (Cd) (Islam et al., 2009). Selain Cd, Zn juga meningkatkan aktivitas peroksidase di tumbuhan akar wangi (Vetiveria zizanioides) (Xu et al., 2009).

Anggraini, (1999), telah menggunakan gen per dari A. thaliana untuk melacak adanya gen per pada beberapa kultivar tanaman kedelai. Dengan menggunakan gen tersebut, (Suharsono et al., 2003) telah melakukan penapisan terhadap pustaka genom untuk mengisolasi gen per dari kedelai kultivar Lumut.

Penelitian ini bertujuan untuk mengisolasi gen per dari pustaka genom kedelai kultivar Slamet melalui penapisan terhadap pustaka genom.

\section{BAHAN DAN METODE}

Bahan. Pustaka genom kedelai kultivar Slamet di dalam fage $\lambda$ Bluestar-1 (Suharsono, 2002) digunakan sebagai bahan penapisan. Bakteri Escherichia coli $(E$. coli) galur ER1647, galur BM25.8, dan galur $\mathrm{DH} 5 \alpha$, masing-masing digunakan sebagai inang untuk amplifikasi fage $\lambda$ rekombinan, proses eksisi dari fage $\lambda$ rekombinan menjadi plasmid Bluestar-1 rekombinan, dan amplifikasi plasmid rekombinan.

Gen peryang diisolasi dari $A$. thaliana (Richards et al., 1998) yang mempunyai homologi lebih dari $98 \%$ dengan gen $p r x \mathrm{Cb}$ dari $\mathrm{A}$. thaliana dengan GenBank EMBL nomer aksesi X71794 (Intapruk et al. 1994) digunakan sebagai pelacak. Gen ini diperbanyak dengan PCR dengan menggunakan primer Atprx $\mathrm{Cb}-\mathrm{F}(1)$ 5'-TCAACTAGTTTTGTTTTTCCTCTT-3' yang terletak pada nukleotida ke-31 sebelum kodon awal dan AtprxCb-R(11755'-GTTCTCAAGTAAACGTCTTGAGAG3') yang terletak pada nukleotida ke-79 setelah kodon akhir dari gen prx Cb berdasarkan GenBank EMBL aksesi X71794.

Isolasi DNA plasmid. DNA plasmid yang mengandung pelacak diisolasi dari E. coli DH5á menggunakan prosedur dari Suharsono (2002). Untuk itu, satu koloni bakteri E. coli DH5á ditumbuhkan di dalam $2 \mathrm{~mL}$ media LB cair ( $10 \mathrm{~g} / \mathrm{L}$ tripton, $5 \mathrm{~g} / \mathrm{L}$ ekstrak khamir, $10 \mathrm{~g} / \mathrm{L} \mathrm{NaCl}$ ) yang mengandung ampisilin 100 ppm pada inkubator bergoyang ( $250 \mathrm{rpm}$ ) dengan suhu $37^{\circ} \mathrm{C}$ selama semalam. Kultur bakteri disentrifugasi dengan kecepatan 16000xg (Jouan BR-4i) pada suhu $4^{\circ} \mathrm{C}$ selama 10 menit. Endapan bakteri disuspensikan dengan 300il buffer suspensi ( $50 \mathrm{mM}$ Tris- $\mathrm{HCl}, \mathrm{pH} 7,5$ dan 10 mM EDTA) kemudian ditambah dengan 300il buffer lisis $(0,2 \mathrm{M} \mathrm{NaOH}$ dan $1 \%$ SDS) dan dibolak balik perlahan beberapa kali. Campuran ditambahi dengan 300il buffer netralisasi (1,32 M Natrium asetat, $\mathrm{pH} 4,8$ ) dan disentrifugasi pada kecepatan $16000 \mathrm{xg}$ pada suhu $4^{\circ} \mathrm{C}$ selama 20 menit. Supernatan diektraksi dengan $1 \times$ volume fenol/kloroform/isoamilalkohol (25/ 24/1) (PCI), kemudian campuran divorteks, dan disentrifugasi pada kecepatan $16000 \mathrm{xg}$ pada suhu $20^{\circ} \mathrm{C}$ selama 5 menit. Supernatan diambil dan dicampur dengan RNAse $(100 \mu \mathrm{g} / \mathrm{mL})$, kemudian larutan ini diikubasikan pada suhu $37^{\circ} \mathrm{C}$ semalam. Larutan kemudian diekstraksi kembali dengan $\mathrm{PCl}$. Supernatan diambil dan ditambahi dengan $0,1 \times$ volume $3 \mathrm{M}$ natrium asetat $\mathrm{pH} 5,2$ dan $2 x$ volume etanol absolut. Larutan diinkubasi pada suhu $-20^{\circ} \mathrm{C}$ selama 2 jam, kemudian disentrifugasi dengan kecepatan $16000 \times$ g pada suhu $4^{\circ} \mathrm{C}$ selama 20 menit. Endapan DNA plasmid dibilas dengan etanol $70 \%$, dikeringkan dengan pengeringvakum, lalu DNA disuspensikan dalam TE (10 mMTris$\mathrm{HCl}, 1 \mathrm{mM}$ EDTA, $\mathrm{pH}$ 8,0).

Isolasi dan pelabelan DNA pelacak. DNA pelacak diperbanyak dengan PCR (Polymerase Chain Reaction). PCR dilakukan dengan menggunakan 30 siklus (PTC-100 ${ }^{\mathrm{TM}}$, MJ Research Inc.) dengan kondisi pra-PCR $94^{\circ} \mathrm{C} 2$ menit, denaturasi $92^{\circ} \mathrm{C} 30$ detik, penempelan primer $55^{\circ} \mathrm{C} 30$ detik, pemanjangan $75^{\circ} \mathrm{C}$ 1 menit, dan pasca-PCR pada suhu $75^{\circ} \mathrm{C} 5$ menit. Hasil PCR dimigrasikan dalam 1,2\% (b/v) agarosa di 
dalam $1 \mathrm{x}$ bufer TAE $(0,04 \mathrm{M}$ Tris-acetate, 0,001 M EDTA).

DNA pelacak diisolasi dari gel agarosa mengikuti metode Suharsono et al., (2003). Gel yang mengandung pita DNA pelacak diambil dengan scalpel, dipotong kecil-kecil dan dimasukkan ke dalam tabung eppendorf berfilter $0,22 \mu \mathrm{m}$ (Ultrafree MC, Millipore) kemudian dimasukkan ke dalam nitrogen cair. Gel agarosa di dalam tabung ditambahi dengan TE $(10 \mathrm{mM}$ Tris $\mathrm{pH}$ 8,0;1 mM EDTA) dan disentrifugasi pada kecepatan $14000 \mathrm{xg}$ selama 5 menit. Perlakuan tersebut dilakukan 3 kali untuk membilas gel agar seluruh DNA dibebaskan dari gel. DNA dalam TE yang tertampung dalam tabung diendapkan dengan penambahan 0,1 volume $3 \mathrm{M}$ natrium asetat $\mathrm{pH} 5,2$ dan 2,5 volume ethanol absolut. Campuran tersebut kemudian diinkubasi pada suhu $-20^{\circ} \mathrm{C}$ selama 2 jam, kemudian disentrifugasi dengan kecepatan $20000 \times g$ pada suhu $4^{\circ} \mathrm{C}$. Endapan DNA kemudian dibilas dengan ethanol $70 \%$, dikeringkan, dan dilarutkan dalam $\mathrm{H}_{2} \mathrm{O}$.

DNA pelacak dilabel dengan alkalin fosfatase menggunakan kit AlkPhos DNA labeling and detection system dari Amersham Pharmacia Biotech. Sebanyak $100 \mathrm{ng}$ DNA pelacak dalam $10 \mu$ ldidenaturasi pada suhu $100^{\circ} \mathrm{C}$ selama 5 menit dan segera dimasukkan ke dalam es selama 5 menit. Suspensi DNA pelacak kemudian ditambahi dengan $10 \mu \mathrm{l}$ buffer pereaksi, $2 \mu \mathrm{l}$ labelling reagent dan $10 \mu \mathrm{l}$ Cross Linker. Campuran diinkubasi pada suhu $37^{\circ} \mathrm{C}$ selama 30 menit.

Keberhasilan isolasi DNA pelacak dengan PCR dideterminasi dengan melakukan elektroforesis DNA hasil PCR di agarosa.

Transfeksi dan pemindahan fage ke membran nilon. Transfeksi fage ë rekombinan ke dalam bakteri E. coli dilakukan dengan mencampur $100 \mu$ l bakteri $E$. coli ER1647 $\left(\mathrm{OD}_{600}=1\right)$ dengan $100 \mu$ fage ë. Untuk penapisan pertama jumlah fage $\lambda$ rekombinan yang digunakan adalah $10^{5} \mathrm{pfu}$ (plaque forming unit), sedangkan untuk penapisan kedua, fage rekombinan yang digunakan sekitar 50 pfu. Campuran diinkubasi di dalam inkubator pada suhu $37^{\circ} \mathrm{C}$ selama 30 menit, dan dimasukkan ke dalam $4 \mathrm{~mL}$ agarosa cair permukaan (molten top agarose) (10 g/l tripton, $5 \mathrm{~g} / \mathrm{L} \mathrm{NaCl}$ dan $6 \mathrm{~g} /$ $\mathrm{L}$ agarosa) yang mempunyai suhu $47^{\circ} \mathrm{C}$. Campuran disebar di atas permukaan media $\mathrm{H}(10 \mathrm{~g} / \mathrm{L}$ tripton, 8 $\mathrm{g} / \mathrm{L} \mathrm{NaCl}, 15 \mathrm{~g} / \mathrm{L}$ agar-agar) di dalam cawan petri dan diikubasi dalam inkubator pada suhu $37^{\circ} \mathrm{C}$ selama semalam.
Setelah transfeksi diinkubasikan semalam di suhu $37^{\circ} \mathrm{C}$, plak yang terbentuk dipindahkan ke membran nilon hybond $\mathrm{N}^{+}$(Amersham, Pharmacia). Untuk itu, membran nilon diletakkan di atas plak yang ada di dalam cawan petri selama 1-3 menit sedemikian rupa sehingga permukaan membran bersentuhan langsung dengan plak. Fage yang terdapat di membran didenaturasi dengan cara meletakkan permukaan membran yang mengandung fage di atas $3 \mathrm{ml}$ larutan denaturasi (1,5 M NaCl; 0,5 M NaOH) selama 3 menit. Dengan cara yang sama, membran kemudian dipindah ke atas $3 \mathrm{~mL}$ larutan netralisasi $(1,5 \mathrm{M} \mathrm{NaCl} ; 0,5 \mathrm{M}$ Tris- $\mathrm{HCl}, \mathrm{pH} 8$ ) selama 3 menit. Setelah dikeringanginkan, DNA fage yang ada di membran nilon difiksasi dengan menggunakan UV cross Linker (Vilber Lourmat BLX-254). Keberhasilan transveksi dilakukan dengan melakukan pengamatan terhadap plak yang terbentuk.

Hibridisasi Southern. Hibridisasi southern dilakukan terhadap DNA di membran baik yang mengandung DNA plasmid maupun DNA fage. Membran dimasukkan ke dalam tabung hibridisasi sedemikian rupa sehingga permukaan yang mengandung DNA menghadap ke dalam tabung, kemudian larutan prehibridisasi $(0,5 \mathrm{M} \mathrm{NaCl}, 5 \%$ blocking reagent) ditambahkan ke dalam tabung. Prehibridisasi dilakukan pada suhu $55^{\circ} \mathrm{C}$ selama 1 jam, kemudian DNA pelacak yang sudah dilabel ditambahkan ke dalam tabung untuk proses hibridisasi. Hibridisasi dilakukan dalam oven hibridisasi dengan suhu $55^{\circ} \mathrm{C}$ selama satu malam. Setelah hibridisasi, membran dicuci $2 x$ dengan larutan pencuci primer (2 M Urea; 0,1\% SDS; $50 \mathrm{mM} \mathrm{Na}$ Phospat pH7; $150 \mathrm{mM} \mathrm{NaCl} ; 1 \mathrm{mM} \mathrm{MgCl}_{2}$ dan $0,2 \%$ Blocking Reagent) masing-masing 10 menit pada suhu $55^{\circ} \mathrm{C}$ disusul dengan $2 x$ pencucian dengan larutan pencuci sekunder ( $1 \mathrm{M}$ Tris; $2 \mathrm{M} \mathrm{NaCl}$; $1 \mathrm{M} \mathrm{MgCl}_{2} \mathrm{pH}$ 10) masing-masing selama 5 menit pada suhu ruang. Setelah ditiriskan, membran dibasahi dengan cairan deteksi CDP-Star ${ }^{T M}$ selama 5 menit. Setelah dibuang dari kelebihan cairan deteksi, membran dibungkus dengan plastik. Film X-ray kemudian diletakkan diatasnya dan ditempatkan di dalam kaset hibridisasi selama 4 jam pada suhu ruang. Film dicuci di dalam ruang gelap berturut-turut dengan larutan developer selama 3 menit, fixer selama 15 menit, dan $\mathrm{H}_{2} \mathrm{O}$. Pengamatan terhadap hasil hibridisasi dilakukan secara kwalitatif dengan memperhatikan terbentuknya signal hibridisasi pada film. 
Isolasi fage dan Eksisi fage menjadi plasmid. Plak-plak yang menunjukkan signal hibridisasi diisolasi dari media $\mathrm{H}$ dengan cara mencungkil gel agar yang Keberhasilan proses tranformasi ditandai dengan terbentuknya koloni $E$. coli yang dapat hidup di media 2xYT yang mengandung ampisilin.

Pemotongan DNA plasmid dan pemblotan DNA di membran. DNA plasmid dipotong dengan enzim restriksi BamH I pada suhu $37^{\circ} \mathrm{C}$ selama semalam dengan mencampur 60 ng DNA, 6 unit enzim BamHI (New England BioLabs), $2 \mu \mathrm{l}$ 10xNEB Buffer BamH I (150 mM NaCl, $10 \mathrm{mM}$ Tris $\mathrm{HCl}, 10 \mathrm{mM} \mathrm{MgCl}, 1 \mathrm{mM}$ dithiothreitol $\mathrm{pH} 7,9$ ) dengan volume total $20 \mu \mathrm{l}$.

Setelah dimigrasikan di dalam 1,2\% gel agarosa, gel berturut-turut direndam di dalam larutan depurinasi $(0,25 \mathrm{M} \mathrm{HCl})$ selama 15 menit, larutan denaturasi $(1,5$ $\mathrm{M} \mathrm{NaCl}, 0,5 \mathrm{M} \mathrm{NaOH}$ ) selama 25 menit dan larutan netralisasi $(1,5 \mathrm{M} \mathrm{NaCl}$; 0,55 Tris- $\mathrm{HCl} \mathrm{pH}$ 7,2; $1 \mathrm{mM}$ EDTA) selama 20 menit. DNA yang di dalam gel dipindahkan ke membran nilon Hybond $\mathrm{N}^{+}$dengan menggunakan alat vakum (VacuGene Pump-Pharmacia Biotech) pada tekanan 60 milibar selama 2 jam. DNA difiksasi di membran UV cross-linker.

Keberhasilan pemotongan DNA diamati dengan UV transiluminator setelah dilakukan elektroforesis di gel agarosa dan diwarnai dengan etidium bromida.

\section{HASIL DAN PEMBAHASAN}

Penapisan terhadap pustaka genom. Fage $\lambda$ rekombinan yang menginfeksi dan melisis bakteri $E$.

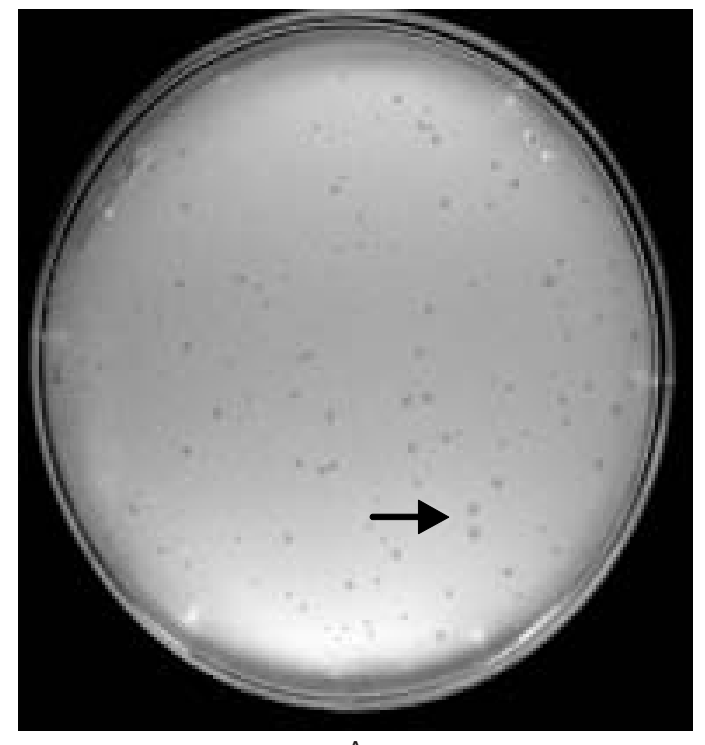

A coli galur ER1647 membentuk plak. Setelah dipindahkan ke membran nilon dan diberi perlakuan berturut-turut dengan larutan denaturasi dan netralisasi, DNA fage rekombinan dicampur dengan gen per dari A. thaliana sebagai DNA pelacak untuk proses hibridisasi southern. Hasil hibridisasi Southern dari penapisan pertama menunjukkan bahwa beberapa plak menunjukkan signal hibridisasi. Fage yang ada di plak diisolasi dari gel agarosa dengan merendam gel yang mengandung plak dalam $500 \mu$ l bufer SM, kemudian diencerkan 100 kali untuk penapisan tahap dua. Pengenceran ini menyebabkan terbentuknya plak yang menyebar dan terpisah satu dengan lainnya pada penapisan kedua (Suharsono et al., 2003). Pada penapisan tahap kedua, hampir semua plak menghasilkan signal hibridisasi (Gambar 1), yang menunjukkan bahwa sebagian besar plak berasal dari fage yang sama.

Eksisi fage ë rekombinan yang mengandung gen sasaran. Eksisi dilakukan terhadap 10 klon fage hasil penapisan tahap kedua yang diambil secara acak. Pengenceran 100 kali dari proses elusi fage dari gel yang kemudian diikuti dengan proses transfeksi ke dalam E. coli galur BM 25,8 memberikan hasil yang tersebar dengan baik. Berkat adanya situs loxP dan adanya rekombinase cre yang dimiliki oleh $E$. coligalur BM 25,8, sisipan di dalam fage dapat keluar untuk membentuk plasmid $\lambda$ Bluestar-1 rekombinan (Suharsono et al., 2002). Proses eksisi menghasilkan koloni bakteri. Dari $10 \mathrm{klon}$ fage yang dilakukan proses eksisi, hanya 5 klon yang dapat menghasilkan koloni.

Gambar 1. Plak (A) dan hasil hibridisasi Southern pada penapisan tahap kedua (B). Tanda panah menunjukkan plak dan sinyal hibridisasi.

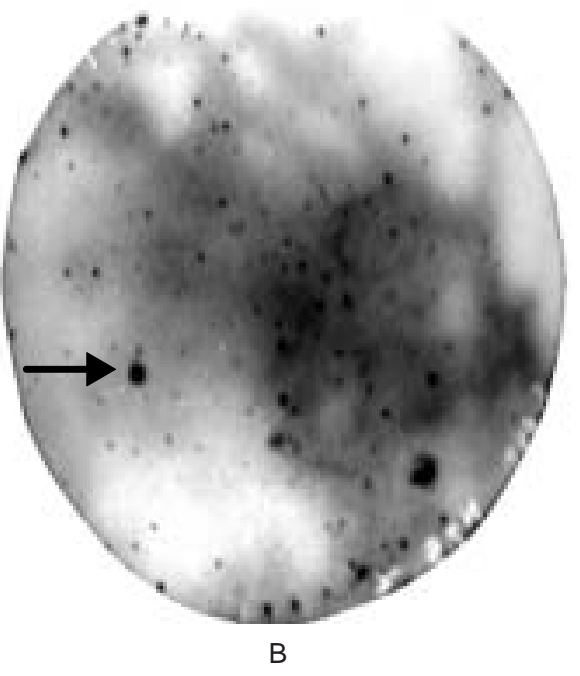



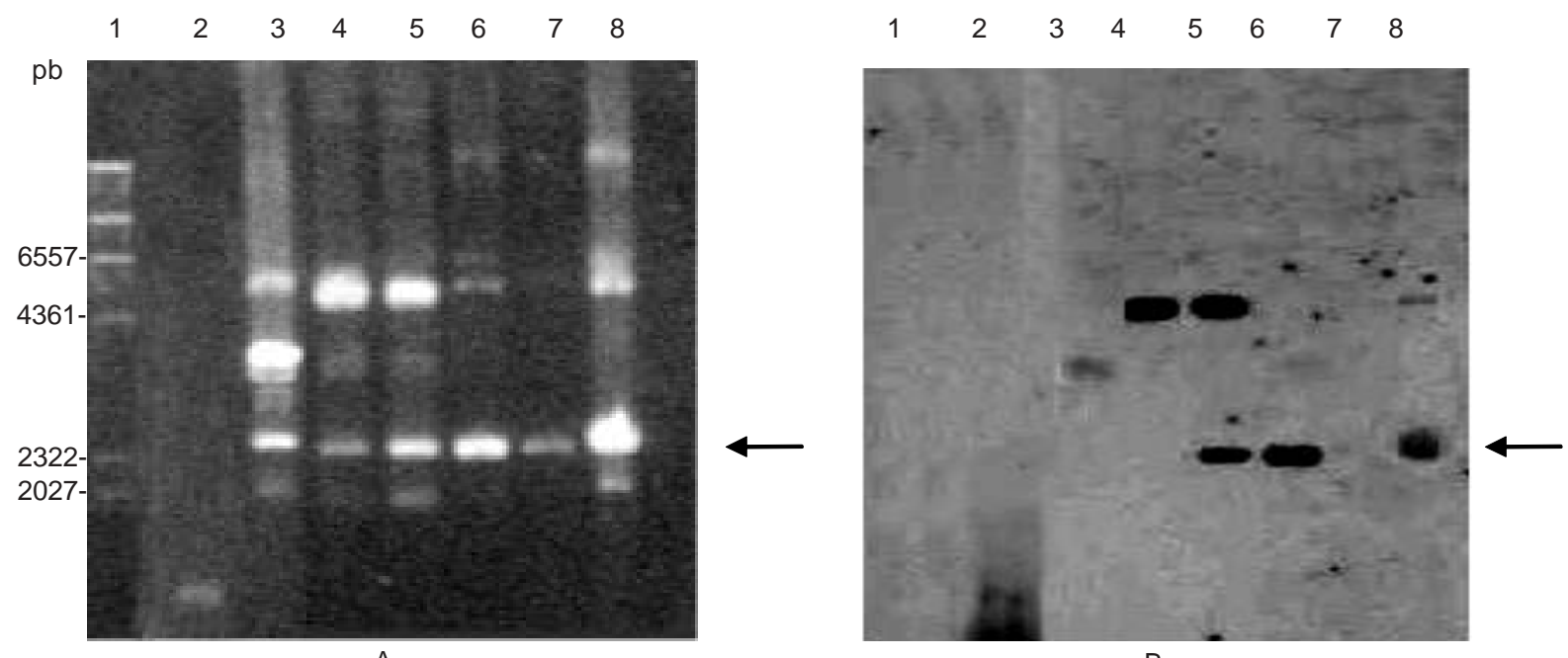

Gambar 2. Hasil elektroforesis DNA plasmid (A) dan hibridisasi Southern dengan gen pelacak per (B). Lajur 1= penanda ukuran $\lambda /$ Hindll; Lajur 2= DNA pelacak; Lajur 3=pS52121R/BamHI; Lajur 4=pS2412R/BamHI; Lajur 5=pS2532R/BamHI; Lajur 6=pS2532R; Lajur 7=pS2412R; Lajur 8= pS52121R. Tanda panah menunjukkan vektor.

Dari setiap proses eksisi diambil secara acak dua koloni BM25,8 untuk diisolasi DNA plasmidnya. DNA plasmid ini kemudian diintroduksikan ke dalam E. coli galur DH5á untuk proses amplifikasi karena galur BM25,8 tidak mendukung proses amplifikasi plasmid.

Analisis DNA sisipan di dalam plasmid rekombinan. Setelah diisolasi, DNA plasmid dipotong dengan restriksi BamHI dan dimigrasikan di gel agarosa, kemudian DNA dipindahkan ke membran nilon. Hibridisasi Southern dengan pelacak gen per dari $A$. thaliana terhadap DNA plasmid menunjukkan bahwa beberapa fragmen $\mathrm{BamHI}$ di dalam plasmid rekombinan mengandung gen per (Gambar 2).

Terdapat tiga klon yang diduga mengandung gen per yaitu pS52121R pS2412R dan pS2532R (Gambar 2). Gen per diduga terdapat pada fragmen $\mathrm{BamHI} 3,7$ kb dari $p S 52121 R$, fragmen $5,3 \mathrm{~kb}$ dari pS2412R, dan fragmen $2,4 \mathrm{~kb}$ dan $5,3 \mathrm{~kb}$ dari pS2532R. Fragmen yang membawa gen perini kemudian diklon ke dalam pSportl.

Gen per yang sudah diisolasi ini sangat penting untuk merakit tanaman yang toleran terhadap berbagai cekaman biotik dan abiotik. Peroksidase terlibat di dalam proses perkembangan dan perkecambahan pada kapas (Ritter et al., 1993), dan pembentukan lignin pada $S$. integrifolium sehingga resisten terhadap ulat (Tsuduki et al., 2006).

Pada bayam ekspresi askorbat peroksidase diinduksi oleh metil viologen dan temperatur tinggi (Yoshimura et al., 2000). Perakitan tanaman transgenik dengan menggunakan gen penyandi peroksidase yang dikombinasikan dengan gen penyandi SOD dapat meningkatkan toleransinya terhadap cekaman metil viologen pada kentang (Tang et al., 2006) dan rumput Festuca arundinacea (Lee et al., 2007), terhadap temperatur yang tinggi (Tang et al., 2006), dan terhadap ion logam berat seperti $\mathrm{Cu}, \mathrm{Cd}$, dan As (Lee et al., 2007). Cekaman Al menginduksi ekspresi gen penyandi peroksidase pada A. thaliana (Richards et al., 1998; Zhao et al., 2009) yang menunjukkan bahwa gen penyandi peroksidase mempunyai peranan yang sangat penting dalam sistem toleransi tumbuhan terhadap cekaman Al. Selain itu, toleransi terhadap Cd dan Zn juga berhubungan dengan aktivitas yang tinggi dari peroksidase (Islam et al., 2009; Xu et al., 2009). Pada padi, ekspresi gen penyandi askorbat peroksidase diinduksi oleh cekaman panas (Sato et al., 2001), dan $\mathrm{NaCl}$ (Hong et al., 2007). Hal ini menunjukkan bahwa peranan peroksidase adalah untuk toleransi tumbuhan terhadap berbagai cekaman abiotik yang menimbulkan oksigen reaktif (reactive oxygen species) yang sangat berbahaya terhadap sel tumbuhan.

\section{KESIMPULAN}

Fage ë rekombinan yang membawa gen per dari kedelai kultivar Slamet telah diisolasi. Setelah mengalami eksisi, beberapa plasmid turunan dari fage ë rekombinan ini mengandung gen perpada fragmenfragmen $\mathrm{BamHI} 3,7 \mathrm{~kb}$ dari pS5212R, 5,3 kb dari pS2412R, 2,4, dan 5,3 kb dari pS2532R.

\section{UCAPAN TERIMA KASIH}

Terima kasih disampaikan kepada Kementerian Negara Riset dan Teknologi yang telah membiayai 
penelitian ini melalui proyek Riset Unggulan Terpadu VIII dengan judul: Isolasi dan karakterisasi gen-gen pada tanaman kedelai yang mendapat cekaman aluminium dengan nomor kontrak 14.18/SK/RUT/2003 tanggal 28 Januari 2003.

\section{DAFTAR PUSTAKA}

Anggraini, V. 1999. Identifikasi gen-gen toleran aluminium pada kedelai menggunakan gen pelacak dari Arabidopsis dan gandum. Tesis Program Pascasarjana. Bogor: Institut Pertanian Bogor.

Hong, C-Y., Hsu, Y.T., Tsai, Y-C., \& Kao, C.H. 2007. Expression of ascorbate peroxidase 8 in roots of rice (Oryza sativa L.) seedlings in response to $\mathrm{NaCl}$. J. Exp. Bot. 58: 3273-83.

Intapruk, C., Takano, M., \& Shinmyo, A. 1994. Nucleotide sequence of a new cDNA for peroxidase from Arabidopsis thaliana. Plant Physiol. 104: 285-286.

Islam, M.M., Hoque, M.A., Okuma, E., Banu, M.N., Shimoishi, Y., Nakamura, Y., \& Murata, Y. 2009. Exogenous proline and glycinebetaine increase antioxidant enzyme activities and confer tolerance to cadmium stress in cultured tobacco cells. Plant Physiol. (In Press, Available online 7 May 2009).

Lee, S.H., Ahsan, N., Lee, K.W, Kim, D.H., Lee, D.G., Kwak, S.S., Kwon, S.Y., Kim, T.H., \& Lee, B.H. 2007a. Simultaneous overexpression of both CuZn superoxide dismutase and ascorbate peroxidase in transgenic tall fescue plants confers increased tolerance to a wide range of abiotic stresses. J. Plant Physiol. 164: 1626-38.

Lee, Y.P., Kim, S.H,, Bang, J.W., Lee, H.S., Kwak, S.S., \& Kwon, S.Y. 2007b. Enhance tolerance to oxidative stress in transgenic tobacco plants expressing three antioxidant enzymes in chloroplast. Plant Cell Rep. 26: 591-598.

Richards, K.D., Schott, E.J., Sharma, Y.K., Davis, K.R., \& Gardner, R.C. 1998. Aluminum induced oxidative stress genes in Arabidopsis thaliana. Plant Physiol. 116: 409-418.

Ritter, D., Allen, R.D., Trolinder, N., Hughes, D.W., \& Galau, G.A. 1993. Cotton Cotyledon cDNA Encoding a Peroxidase. Plant Physiol. 102: 1351.

Sato, Y., Murakami, T., Funatsuki, H., Matsuba, S., Suruyama, H., \& Tanida, M. 2001. Heat shock-mediated APX gene expression and protection against chilling injury in rice seedlings. J. Exp. Bot. 52: 145-151.
Suharsono. 2002. Kontruksi pustaka genom kedelai kultivar Slamet. Hayati 9: 67-70.

Suharsono, Anwar, S., Jusuf, M., \& Widyastuti, U. 2003a. Isolasi dan karakterisasi gen-gen dari tanaman kedelai yang mendapat cekaman aluminium. Laporan riset RUT VIII bidang bioteknologi. Jakarta: Kementerian Riset dan Teknologi dan Lembaga Ilmu Pengetahuan Alam.

Suharsono, Julianto, T., \& Jusuf, M. 2003b. Isolasi gen penyandi peroksidase dari kedelai kultivar lumut melalui penapisan terhadap pustaka genom. Simposium Bioteknologi dan Sumberdaya Genetik, Balitbiogen Pertanian. Bogor, 11-12 Desember 2003.

Syarifuddin, A. \& Abdurachman, A. 1993. Optimasi pemanfaatan sumberdaya lahan berwawasan lingkungan. Prosiding Simposium Penelitian Tanaman Pangan III. Pusat Penelitian dan Pengembangan Tanaman Pangan dan Badan Litbang Deptan. Jakarta/Bogor, 23-25 Agustus 1993.

Tang, L., Kwon, S.Y., Kim, S.H., Kim, J.S., Choi, J.S., Cho, K.Y., Sung, C.K., Kwak, S.S., \& Lee, H.S. 2006. Enhance tolerance of transgenic potato plants expressing both superoxide dismutase and ascorbate peroxidase in chloroplasts against oxidative stree and high temperature. Plant Cell Rep. 25: 1380-1386.

Tsuduki, M., Takano, T., Nakatsubo, F., Yoshida, K., Shinmyo, A., \& Asao, H. 2006. Resistance to insects in transgenic Solanum plants expressing a peroxidase gene from horseradish. Plant Biotechnol. 23: 71-74.

Zhao, C.R., Ikka, T., Sawaki, Y., Kobayashi, Y., Suzuki, Y., Hibino, T., Sato, S., Sakurai, N., Shibata, D., \& Koyama H. 2009. Comparative transcriptomic characterization of aluminum, sodium chloride, cadmium and copper rhizotoxicities in Arabidopsis thaliana. BMC Plant Biol 9: 32

Xu, W., Li, W., He, J., Balwant, S., \& Xiong, Z. 2009. Effect of insoluble $\mathrm{Zn}, \mathrm{Cd}$, and EDTA on the growth, activities of antioxidant enzymes and uptake of $\mathrm{Zn}$ and $\mathrm{Cd}$ in Vetiveria zizanioides. J. Environ. Sci. (China) 21: 186-92.

Yoshimura, K., Yabuta, Y., Ishikawa, T., \& Shigeoka, S. 2000. Expression of spinach ascorbate peroxidase isoenzymes in response to oxidative stresses. Plant Physiol. 123: 223233. 